\title{
Ekim Devriminin Mirası: Kızıl ve Beyazların Savașı
}

\author{
Legacy of the October Revolution: The War of the \\ Red and Whites
}

\section{Ramin Sadygov. The Bloody Four Years-The History of the Russian Civil War (1917-1920). Ankara: Nobel Publications, 2020, 411 Pages, ISBN: 978-625-406-476-0.}

\author{
Tekin Aycan TAȘCI ${ }^{1}$
}

\begin{abstract}
${ }^{1}$ Sorumlu yazar/Corresponding author:
Tekin Aycan Taşcı (Dr.), Erciyes Üniversitesi, Edebiyat Fakültesi, Tarih Bölümü, Kayseri, Türkiye. E-posta: aycantt@gmail.com ORCID: 0000-0001-6340-035X

Başvuru/Submitted: 07.05.2021 • Kabul/Accepted: 01.09.2021 • Online Yayın/Published Online: 22.10 .2021

Atıf/Citation: Tasci, Tekin Aycan. “Ekim Devriminin Mirası: Kızıl ve Beyazların Savaşı, adlı eserin tanıımı. Türkiyat Mecmuası-Journal of Turkology 31. Advanced online publication. https://doi.org/10.26650/iuturkiyat.935782
\end{abstract}

Anahtar kelimeler: Ekim Devrimi, Rus iç savaşı, Bolşevikler, Kızıl Ordu, Beyaz Ordu

Keywords: The October revolution, Russian Civil War, Bolsheviks, Red army, White army

Son yıllarda Türkiye'deki Rusya tarihi araştırmalarında 1905 ve 1917 devrimler dönemine ait konulara ilginin arttığı görülmektedir. Buna en yakın örnek olarak Hasip Saygılı’nın kaleminden “1905 Rus Devrimi ve Sultan Abdülhâmid” adlı çalışma, Ülkü Çalışkan'ın kaleme aldığı “Rusya İmparatorluğu'nda Anayasal Demokrat Partisi'nin Milliyetler Politikası (Kadet Partisi 1905-1917)" adlı çalışma ile Onur İşçi ve Onur Önol'un 2019 yılında yayımlanan “Rusya İmparatorluğu'nun Çöküşü: Harp Yahut İhtilal” adlı eserler gösterilebilir. Bunlardan sonuncusu 1881-1917 y1lları arası dönemi incelemekte olup 300 yıllık Rusya İmparatorluğu'nun aşama aşama nasıl devrime sürüklendiğini başarılı bir şekilde okuyucuya sunmaktadır. 
Söz konusu döneme dair Türkçe literatüre katkıda bulunan bir başka eser 2020 yılında yayımlanan Ramin Sadıgov'a ait "Kanlı Dört Yıl-Rus İç Savaş Tarihi (1917-1920)" adlı çalışmadır. Sadıgov'un kaleme aldığı bu eser, gerek kronolojik olarak İşçi ve Önal'ın çalışmasının devamı niteliğinde olması gerekse doğrudan 1917 devrimi sonrası Rusya'da yaşanan Sovyet hükümeti ile muhalifleri arasındaki silahlı mücadeleye dair Türkiye'de yapılmış ilk kapsamlı çalışma olması dolayısıyla ülkemizdeki Rusya araştırmalarına önemli katkıda bulunmuştur.

Eser Rusya Federasyonu Devlet Arşivi, Sovyet Ordusu Merkez Devlet Arşivi, Rusya Devleti Sosyal-Siyasi Tarih Arşivi, Rusya Devleti Askeri Tarih Arşivi, Rusya Devleti Tarih Arşivi gibi Rusya'nın önde gelen arşivlerine ait belgeler başta olmak üzere döneme ait gazetelerden, Sovyet dönemi ve sonrasına ait çok sayıda Rusça telif eserden oluşan zengin bir kaynakçaya sahiptir. Kitabın içeriği kronolojik usulle hazırlanmış olup girişten sonra 1917-1920 arası dönem, yıllara göre dört bölüm ve onları oluşturan alt başlıklar hâlinde incelenmiştir. Kitabın sonunda yazar, iç savaşın önemli liderlerinin fotoğraflarına; 1919 ve 1920 senelerine ait cephelerin haritalarına ve iç savaş dönemine ait çeşitli fotoğraf karelerine yer vermiştir.

Kitabın ön sözünde yazar, Bolşeviklerin iktidara gelişiyle birlikte patlak veren iç savaşın tarafları Kızıllar, Beyazlar ve Yeşillerden bahsettikten sonra bu savaş hakkında Sovyet dönemi ve sonrası Rus tarih yazımındaki tartışmalara değinmiş, bu minvalde de çalışmanın konusunu ve tarihî sınırlarını açıklamıştır.

Eserin giriş bölümü, Rus toplumunda yol açtığı sosyal, ulusal, politik ve ideolojik bölünmeler sebebiyle Rus iç savaşının zeminini hazırlayan 1905-1917 devrimleri arasındaki süreci ele almaktadır. Bu çerçevede "Kanlı Pazar" adıyla tarihe geçen olay ve sonrasında Ağustos 1905’te Duma'nın kurulması, bu süreçte ortaya çıkan siyasi partiler, II. Nikolay’ın Birinci Dünya Savaşı'na katılması ve bunun sebep olduğu ağır ekonomik durumun sosyal barışı nasıl sona erdirdiği anlatılmaktadır.

1917 yılını konu edinen çalışmanın birinci bölümü (s. 13-108) sırasıyla Şubat Devrimi ve sonrasında kurulan Geçici Hükümet dönemi ile Ekim Devrimi'nden Bolşeviklerin Kurucu Meclis'i feshine kadarki süreci kapsamaktadır. Bu hâliyle 12 alt başlıktan oluşan bölümde Bolşeviklere karşı başlatılan isyanlar, Bolşeviklerin Sol SR Partisi ile koalisyonu ve Moskova'da yönetimi ele almaları, Rus Ordusu Genel Karargâhı'nı ele geçirmeleri, General Kaledin ve Aleksandr Dutov'un isyanları ve Bolşeviklerin Almanlarla BrestLitovsk barış görüşmelerine başladığı uzun süreç ele alınmaktadır. Yazar bu bölümü yıllardır açılması beklenen Kurucu Meclis'in sadece bir gün çalıştıktan sonra Bolşevikler tarafından feshedilmesi ile sonlandırmıştır.

Yazarın ifadesiyle Bolşeviklerin Kurucu Meclis’i kapatarak ülkede tek partili diktatöryel bir rejim kurmaya çalışmaları ve imzaladıkları Brest Litovsk Barışı ile ülke topraklarının önemli bir kısmını terk etmek suretiyle Birinci Dünya Savaşı'ndan çekilmeleri muhalefette 
infial yaratmış, bu da iç savaşın daha da şiddetlenmesine yol açmıştır.

1918 yılında yaşanan bu gelişmelerin 13 alt başlık hâlinde ele alındığı ikinci bölümde (s. 109-196) Bolşeviklerin kendilerine muhalif bölge ve hükümetler ile mücadelelerine yer verilmiştir. Bölümde kısa bir girişten sonra ilk olarak Eylül 1917'den beri sorun teşkil eden General Lavr Kornilov’un Bolşeviklere karşı son savaşı, 1918 yılının ilkbaharında Bolşeviklerin Kızıl Ordu'yu kurmaları, Rusya için adeta bir felakete dönüşen Brest Litovsk Antlaşması'nın imzalanması, Sol SR'lerin Sovyet hükümetine karşı isyanından bahsedilmiştir. Bölümde değinilen önemli meselelerden biri de günümüze dek Rus toplumunda bir travma etkisi yaratan II. Nikolay ve ailesinin katledilmesi hadisesidir. Bu olay Bolşevik muhaliflerinde büyük bir infiale neden olduğu gibi kan davası hüviyeti kazandırdığı iç savaşı daha da derinleştirmiştir. Bunların dışında Sovyet hükümetinin iç savaş yıllarında savaş komünizmi adı altında uyguladığg ekonomik program, ülkede bulunan Çekoslovak kolordusunun isyanı neticesinde Volga'dan Vladivostok'a kadar Bolşevik yönetimlerin yıkıldı̆̆ı bölgelerde kurulan muhalif hükümetler ve sonrasında burada Bolşeviklerle muhalifler arasında yaşanan hâkimiyet mücadeleleri, bölümde üzerinde durulan diğer konulardır. Bölümün son konusu ise müttefik devletler İngiltere, Fransa, ABD ve Japonya'nın Rusya'ya asker çıkarması hadisesidir. 1918-1920 yılları arası dönemi kapsayan bu işgal hareketi, Rus iç savaşını Bolşevikler lehine döndürmesi bakımından önemlidir. Nitekim yazarın da ifadesiyle o zamana kadar Bolşevik iktidarına mesafeli duran halk, onu yıkmaya çalışan muhaliflerin işgalcilerle iş birliği yapmasına tepki göstererek safını vatan savunması mottosuyla hareket eden Bolşeviklerden yana belirlemiştir.

Eserin üçüncü bölümünde (s. 197-301) 1919 y1lı beş alt başlık hâlinde incelenmektedir. 1919 yılı, iç savaşın gidişatını belirleyen gelişmelere sahne olduğu için yazarın da tanımıyla Bolşeviklerin kader yılı olmuştur. Öyle ki 1918 yazı ve sonbaharında ülkenin doğusunda aldığı zaferlerle üstünlüğü ele geçiren Sovyet yönetimi, 1919'da doğu, güney, güney-bat1, kuzey ve kuzey-batıdan müttefik devletlerin desteğindeki muhalif orduların saldırısına maruz kalmış ve oldukça güç duruma düşmüştür. Bolşevikler durumu ancak 1919 yılının sonlarına doğru değiştirmeye muvaffak olabilmişlerdi. Dolayısıyla Sovyet hükümeti ile muhalifler arasındaki mücadelelerin incelendiği bu bölümde ilk olarak Omsk’ta direktuvarlık hükümetinin devrilmesiyle iktidara gelen Aleksandr Kolçak’ın Bolşeviklere karşı verdiği mücadele ve akıbeti anlatılmıştır. Sonrasında Kolçak'ın ardından gönüllü ordunun başına geçen bir diğer muhalif General Anton Denikin'in Sovyet hükümetine karşı Rusya'nın güneyinde cephe oluşturması ve kısa bir süre içinde Ukrayna, Kuban ve Don'un tamamı da dâhil olmak üzere Bolşeviklerden 810.000 kilometrekare toprak kazanarak edindiği başarılarından söz edilmiştir. Son olarak ise General Nikolay Yudeniç'in mücadelesi ve Petrograd üzerine taarruzu, Denikin'e karşı Kızıl Ordu'nun güney cephesinde inisiyatifi ele alması ve Kuzey'de Bolşeviklere karşı Yevgeniy Miller hükümetinin kurulması konuları üzerinde durulmuştur. 
Eserin son bölümü (s. 303-368) Bolşeviklerin zafer yılı olan 1920 senesine ayrılmıştır. Dört alt başlıktan oluşan bu bölümde ilk olarak 1919 senesindeki başarılarından sonra Moskova'ya yaklaşan muhalif General Denikin'in mağlubiyeti konu edilmiştir. Ardından Güney Rusya Orduları Başkomutanı Baron P. Vrangel'in faaliyetleri, Kızıl Ordu ile mücadelesi ve sonunda mağlup olmasına yer verilmiştir. Ayrıca Vrangel ile mücadele sırasında Transbaykal bölgesinde tehdit unsuru olarak görülen Ataman G. Semyonov'un 1920 sonlarında bertaraf edilmesine kadar olan dönemdeki mücadelelerine de değinilmiştir. Yazar bu bölümün sonunda Bolşeviklerin iç savaşı nasıl kazandıkları, muhaliflerin ise neden kaybettikleri sorularına cevap aramıştır. Bu kapsamda yazar, Bolşevikler ile muhaliflerin toplum nezdindeki karşılıkları, lider ve ideoloji bakımından kıyasları, kendi içlerindeki birlik ve bütünlüğü sağlamadaki başarıları, askerî, teknolojik ve maddi açılardan kapasiteleri, hâkimiyeti kurmak için başvurdukları yöntemler ve halkın düştüğü ekonomik sıkıntıların iki tarafın mücadelesine nasıl etki ettiği gibi konular üzerinde durmuştur.

Sonuç bölümünde Rus iç savaşına dair genel değerlendirmelerini paylaşan yazar, muhalifleri yenilgiye götüren nedenleri Beyaz Ordu'nun tek merkezden yoksun parçalanmış vaziyeti, yönetici subayları arasındaki anlaşmazlıklar, Müttefiklerden aldıkları desteğin tepki doğurması, propaganda ve halkla iletişimdeki zayıflıkları çerçevesinde tahlil etmiştir. İç savaştan sonra Bolşeviklerin ideolojilerine uygun yeni bir toplum ve yeni bir ülke tesis etmeyi sürdürdüklerine vurgu yapan yazar, yaşanan iç savaşın insani boyutuna da dikkat çekmiş, savaş sebebiyle ekonomik, toplumsal, kültürel ve siyasal bir çöküntüye uğrayan Rusya'da asıl kaybedenin Rusya halkı olduğu değerlendirmesinde bulunmuştur.

Kitabın kaynakça kısmına dair bazı teknik eleştirilerde bulunmak mümkündür. Kaynakçada eleştiriye açık hususların başında arşiv belgelerinin künyeleri gösterilebilir. Yazar, kullandığı arşiv belgelerini kaynakçada yaprak numaralarıyla belirtmiş ve buna istinaden de aynı belgeyi birkaç kez yazmıştır. Diğer taraftan yazar arşiv belgelerini sıralarken delo (dosya) numaralarını da dikkate alabilirdi. Arşiv belgelerinin künyeleriyle ilgili bir başka husus Türkçe arşiv tasnif sisteminde "gömlek" olarak tercüme edebileceğimiz onucb (opis) teriminin transkripsiyonu dipnot ve kaynakçada "opıt" olarak yapılmıştır. Bunların dışında kitabın künye kısmında editörün yazara notu gözden kaçan editöryel hata olarak dikkat çekmektedir.

Netice itibarıyla Ramin Sadıgov tarafından kaleme alınan kitap, Bolşeviklerin iktidarı ele geçirmesinin ardından başlayan iç savaşın 1917-1920 yılları arasındaki sürecini tüm yönleriyle olabildiğince objektif şekilde tahlil etmekte ve konuyu akıcı bir akademik üslupla okuyucuya aktarmaktadır. Eserin önemini arttıran bir diğer husus ise doğrudan Rus iç savaş1 tarihini inceleyen Türkiye'de kaleme alınmış en kapsamlı ilk çalışma olmasıdır. Bu yönüyle kitap, ülkemizdeki Sovyet tarihi araştırmaları için başucu niteliğinde bir eser olarak Türkçe literatüre zenginlik katmıştır. 